\title{
Pengaruh Penerapan Model Pembelajaran Problem Based Instruction (PBI) terhadap Kemampuan Berpikir Kreatif Matematis berdasarkan Kemandirian Belajar Siswa Sekolah Menengah Atas
}

\author{
Witri Marsinia ${ }^{1}$, Depriwana Rahmi ${ }^{2}$. \\ ${ }^{2}$ Program studi Pendidikan Matematika, Universitas Islam Negeri Sultan Syarif Kasim Riau \\ e-mail: witri.marsinia@students.uin-suska.ac.id,depriwanar@gmail.com
}

\begin{abstract}
ABSTRAK. Penelitian ini dilatar belakangi oleh adanya fakta dilapangan yang menunjukkan masih terdapat siswa SMA Negeri Plus Provinsi Riau yang belum optimal memiliki kemampuan berpikir kreatif. Adapun tujuan penelitian ini adalah untuk menyelidiki ada tidaknya perbedaan kemampuan berpikir kreatif matematis antara siswa yang mengikuti model pembelajaran Problem Based Instruction (PBI) dengan siswa yang mengikuti pembelajaran konvensional, mengetahui ada tidaknya perbedaan kemampuan berpikir kreatif matematis antara siswa yang mengikuti model pembelajaran Problem Based Instruction (PBI) dengan siswa yang mengikuti pembelajaran konvensional jika dilihat berdasarkan kemandirian belajar serta melihat ada tidaknya interaksi antara model pembelajaran Problem Based Instruction (PBI) dengan kemampuan berpikir kreatif matematis siswa. Penelitian ini merupakan penelitian Quasi Eksperimental dengan desain randomized control group pretest-pascatest design. Populasi dalam penelitian ini adalah seluruh siswa kelas X MS semester genap SMA Negeri Plus Provinsi Riau tahun ajaran 2017/2018. Sampel yang diambil secara acak adalah kelas X MS 2 dan X MS 4. Analisis data yang digunakan untuk hipotesis 1 menggunakan uji-t sedangkan untuk hipotesis 2 dan 3 menggunakan anova dua arah. Hasil analisis data dengan menggunakan uji t menunjukkan nilai $t_{\text {hitung }}=2,7500>t_{\text {tabel }}=2,0106$ sehingga dapat disimpulkan terdapat perbedaan kemampuan berpikir kreatif matematis antara siswa yang mengikuti model pembelajaran Problem Based Instruction (PBI) dengan siswa yang mengikuti pembelajaran konvensional di SMA Negeri Plus Provinsi Riau. Hasil analisis data dengan menggunakan anova dua arah menunjukan $F(B)_{\text {hitung }}=32,80>F(B)_{\text {tabel }}=3,21$ dengan demikian dapat diambil kesimpulan bahwa jika berdasarkan aspek kemandirian belajar, terdapat perbedaan kemampuan berpikir kreatif matematis antara siswa yang mengikuti pembelajaran Problem Based Instruction (PBI) dengan siswa yang mengikuti pembelajaran konvensional di SMA Negeri Plus Provinsi Riau. Sedangkan untuk interaksi $F(A \times B)_{\text {hitung }}=-3,52<F(A \times$ $B)_{\text {tabel }}=3,21$ sehingga dapat ditunjukan bahwa tidak terdapat interaksi faktor kemandirian belajar terhadap kemampuan berpikir kreatif matematis siswa.
\end{abstract}

Kata Kunci: Model Pembelajaran PBI, Kemampuan Berpikir Kreatif Matematis, Kemandirian Belajar Siswa.

\section{PENDAHULUAN}

Menurut Permendikbud Nomor 21 Tahun 2016 tentang Standar Isi Pendidikan Dasar dan Menengah menetapkan bahwa kompetensi yang harus dicapai pada pelajaran matematika adalah (1) Menunjukkan sikap logis, kritis, analitis, kreatif, cermat dan teliti, bertanggung jawab, responsif, dan tidak mudah menyerah dalam memecahkan masalah (2) Memiliki rasa ingin tahu, semangat belajar yang kontinu, rasa percaya diri, dan ketertarikan pada matematika (3) Memiliki rasa percaya pada daya dan kegunaan matematika, yang terbentuk melalui pengalaman belajar (4) 
Memiliki sikap terbuka, objektif dalam interaksi kelompok maupun aktivitas sehari-hari (5) Memiliki kemampuan mengkomunikasikan gagasan matematika dengan jelas. Salah satu kemampuan yang harus dimiliki oleh peserta didik dalam Permendikbud Nomor 21 Tahun 2016 adalah kemampuan berpikir kreatif matematis, yaitu berpikir kreatif dalam memecahkan masalah.

Kreativitas perlu dikembangkan guna mengembangkan potensi anak secara utuh dan bagi kemajuan ilmu pengetahuan dan seni (Syam, 2015:107). Kemampuan berpikir kreatif merupakan bagian yang sangat penting untuk kesuksesan dalam pemecahan masalah. Seperti yang dikemukakan oleh Evans, J. R dalam Syafti (2016:158), sikap positif terhadap pemecahan masalah dapat meningkatkan keberhasilan seseorang dalam pemecahan masalah, jadi berpikir kreatif dapat mempertinggi sikap positif seseorang dengan tidak mengenal putus asa dalam menyelesaikan masalah. Berdasarkan aspek pemecahan masalah matematis, pemikiran-pemikiran kreatif diperlukan dalam membuat (merumuskan), menafsirkan dan menyelesaikan masalah serta berpikir kreatif matematis. Karena itu, berpikir kreatif sangat penting untuk keberhasilan pemecahan masalah. Namun, beberapa penelitian terdahulu menunjukkan bahwa kemampuan berpikir kreatif matematis peserta didik Indonesia masih terbilang rendah.

Penelitian yang dilakukan Asterina (2015) di SMP Negeri 6 Cimahi tahun ajaran 2014/ 2015 yang dilakukan penulis mengenai kemampuan berpikir kreatif matematis siswa, diperoleh bahwa untuk kemampuan berpikir kreatif: 20\% berpikir lancar (fluency), 25\% berpikir luwes (flexibility), $13 \%$ berpikir orisinal (originality), dan 25\% berpikir elaborative (elaboration). Hal ini diperkuat oleh penelitian Widiani (2016) di Madrasah Aliyah Negeri (MAN) 1 Pontianak yang menemukan bahwa kemampuan berpikir kreatif siswa dalam aspek kelancaran, keluwesan, keaslian dan keterperincian juga tergolong rendah. Penelitian lainnya yang dilakukan oleh Jallen dan Urban dalam Anggraini (2012) yang menyatakan dari hasil penelitiannya menyimpulkan bahwa tingkat berpikir kreatif anak-anak Indonesia menempati urutan terendah. Secara berturutturut dari yang tinggi sampai yang terendah adalah Filipina, Amerika, Inggris,Jerman, India, RRC, Kamerun, Zulu dan Indonesia.

Meninjau studi PISA (2012) beberapa tahun sebelumnya belum menunjukan hasil yang memuaskan. Hasil studi tahun terakhir yaitu tahun 2015 dengan skor 386 dalam bidang kompetensi matematika mengalami kenaikan jika dibandingkan dengan tahun 2012 dengan skor 375. Namun, jika dibandingkan dengan rata-rata keseluruhan yaitu 490 tingkat capainya masih di bawah rata-rata. Selian itu, hasil studi TIMSS pada tahun 2015 mengungkapkan bahwa siswa Indonesia perlu penguatan kemampuan mengintegrasikan informasi, menarik simpulan, serta menggeneralisir pengetahuan yang dimiliki ke hal-hal yang lain. Siswa Indonesia masih perlu dikembangkan lagi untuk kemampuan matematika tingkat tinggi, salah satu berpikir tingkat tinggi adalah kemampuan berpikir kreatif.

Peneliti melakukan wawancara kepada guru mata pelajaran matematika kelas X MS 4. Dari hasil wawancara tersebut peneliti memperoleh informasi bahwa: (1) Sikap rasa ingin tahu siswa terhadap materi yang akan dipelajari masih kurang sehingga siswa cenderung melakukan aktivitas lain dalam proses pembelajaran (2) Siswa hanya menghafal konsep dan kurang mampu menggunakan konsep tersebut jika menemui masalah dalam kehidupan nyata yang berhubungan dengan konsep yang dimiliki (3) siswa tidak dapat menemukan kebenaran suatu pertanyaan dalam artian siswa merasa tidak percaya dengan jawabannya (4) siswa tidak dapat memberikan ide atau cara selain yang terdapat dalam buku dan penjelasan dari gurunya (5) ketika diberikan soal khususnya soal latihan, kebanyakan siswa masih belum mampu mengembangkan suatu gagasan.

Selain melakukan wawancara, peneliti juga melakukan observasi dikelas X MS 4 SMA Negeri Plus Provinsi Riau. Berdasarkan observasi proses pembelajaran matematika dikelas X MS 4 SMA Negeri Plus Provinsi Riau menunjukan bahwa telah banyak usaha yang dilakukan guru untuk meningkatkan kemampuan berpikir kreatif matematis siswa. Beberapa diantaranya adalah dengan mengulang kembali materi yang belum dipahami siswa, mengadakan pembelajaran 
kooperatif dan memperbanyak latihan soal. Guru telah berupaya untuk melaksanakan kegiatan pembelajaran, namun pada kenyataannya pada saat guru memberikan soal latihan dan meminta siswa untuk dapat menjawab soal dengan beberapa penyelesaian, hanya beberapa orang siswa yang dapat menyelesaikannya. Siswa dengan kemampuan rendah cenderung untuk menunggu jawaban dari temannya.

Dari uraian tersebut model pembelajaran yang ditawarkan oleh peneliti untuk meningkatkan kemampuan berpikir kreatif matematis siswa kelas X SMA Negeri Plus Provinsi Riau adalah dengan menerapkan model pembelajarn PBI. Model pembelajaran ini sesuai dengan kurikulum yang digunakan saat ini yaitu Kurikulum 2013, dimana siswa yang harus aktif berinteraksi dengan guru maupun siswa lain. Model Problem Basad Instruction (PBI) merupakan model pembelajaran yang didasarkan pada banyaknya permasalahan yang membutuhkan penyelidikan autentik yakni penyelidikan yang membutuhkan penyelesaian nyata dari permasalahan yang nyata. Model pembelajaran PBI bukan hanya sekedar model mengajar, tetapi juga merupakan suatu model berpikir dan efektif untuk pengajaran proses berpikir tingkat tinggi (Sohaimin:2013). Pembelajaran ini membantu siswa untuk memproses informasi yang sudah jadi dalam benaknya dan menyusun pengetahuan mereka sendiri.

Berdasarkan uraian permasalahan yang dikemukakan dan dengan adanya solusi yang ditawarkan, bila dikaitkan dengan kemandirian belajar yang merupakan salah satu faktor penting dari keadaan individu yang mempengaruhi belajar dan dapat didefenisikan sebagai cara siswa untuk menunjukkan rasa tanggung jawab dalam mengatur, mendisiplinkan diri, serta kemampuan siswa dalam mengembangkan kemampuan belajarnya atas kemauannya sendiri. Sehingga, kemandirian belajar siswa dapat dijadikan tolak ukur untuk mencapai hasil yang baik (Amir Z \& Risnawati, 2015: 168). Karakteristik dalam kemandirian belajar menggambarkan keadaan personalitas individu yang tinggi dan memuat proses metakognitif dimana individu secara sadar merancang, melaksanakan dan mengevaluasi belajarnya. Kebiasaan ini akan menumbuhkan keinginan yang kuat dalam belajar dan dapat membentuk individu yang tangguh, ulet, bertanggung jawab dan berprestasi tinggi (Hendriana \& Sumarmo, 2017: 228). Sikap kemandirian seperti ini, perlu ditanamkan pada diri siswa sejak dini. Hal ini dilakukan dalam rangka mengembangkan sikap yang dapat berdiri sendiri sehingga anak akan tumbuh menjadi pribadi yang mampu berinisiatif, penuh kreatifitas, disiplin dan bertanggung jawab.

Melihat tingkat kemandirian belajar siswa yang berbeda yang mempengaruhi kemampuan berpikir kreatif dalam penerapan model pembelajaran Problem Based Instuction (PBI) yang merupakan salah satu model pembelajaran yang ditawarkan guna membantu siswa untuk meningkatkan kemampuan berpikir kreatif dengan baik melalui diskusi kelompok. Oleh karena itu peneliti tertarik melakukan penelitian eksperimen dengan judul "Pengaruh Penerapan Model Pembelajaran Problem Based Instruction (PBI) terhadap Kemampuan Berpikir Kreatif Matematis berdasarkan Kemandirian Belajar Siswa Sekolah Menengah Atas Negeri Plus Provinsi Riau"

\section{METODE}

Jenis penelitian eksperimen yang digunakan adalah Quasi Eksperimental atau eksperimen semu, dimana variabel penelitian tidak memungkinkan untuk dikontrol secara penuh. Desain yang digunakan dalam penelitian ini adalah randomized control group pretest-pascatest design (Wina Sanjaya,2013: 100). Populasi dalam penelitian ini adalah seluruh siswa kelas X MS semester genap SMA Negeri Plus Provinsi Riau tahun ajaran 2017/2018 yang berjumlah 100 siswa dan terdiri dari 4 kelas. Peneliti mengambil sampel kelas X MS 4 sebagai kelas eksperimen dan kelas X MS 2 sebagai kelas kontrol dengan masing-masing jumlah siswa 25 orang. Pengambilan sampel diambil dengan teknik cluster random sampling yaitu pengambilan anggota sampel yang dilaksanakan berdasarkan gugus atau kelompok, yang mana anggota sampel bukan individu-individu dari 
populasi melainkan kelompok-kelompok individu (Wina Sanjaya, 2013: 232). Kemandirian belajar siswa, digunakan skala non-test diawal pada kelas eksperimen dan kelas kontrol. Skala kemandirian belajar siswa akan dibagi menjadi tiga tingkatan yaitu tinggi, sedang dan rendah. Rancangan penelitian model pembelajaran dan kemandirian belajar terhadap kemampuan berpikir kreatif matematis dimodifikasi dari Furchan (2011: 389)

Tabel I. Hubungan Model Pembelajaran PBI dan Kemandirian Belajar dengan Kemampuan Berpikir Kreatif Matematis Matematis

\begin{tabular}{|c|c|c|}
\hline Kelas & Eksperimen $\left(A_{1}\right)$ & Kontrol $\left(A_{2}\right)$ \\
\hline Kemandirian Belajar & $A_{1} B_{1}$ & $A_{2} B_{1}$ \\
\hline Tinggi $\left(B_{1}\right)$ & $A_{1} B_{2}$ & $A_{2} B_{2}$ \\
\hline Sedang $\left(B_{2}\right)$ & $A_{1} B_{3}$ & $A_{2} B_{3}$ \\
\hline Rendah $\left(B_{3}\right)$ &
\end{tabular}

Teknik pengumpulan data yang digunakan dalam penelitian ini adalah wawancara, Observasi, Teknik dokumen, dan Tes (Lestari,K.E \& Ridwan M, 2017:164). Tes yang dilakukan peneliti ada 2 yaitu: Soal pretest dan pascatest. Angket dalam penelitian ini menggunakan skala Likert. Skala Likert ini memilki dua bentuk pernyataan, yaitu pernyataan positif dan negatif. Pada pernyataan positif diberi skor 4, 3, 2, 1; sedangkan pada pernyataan negatif diberi skor 1, 2, 3, 4 . Bentuk pilihan jawaban skala Likert dari Sangat Setuju (SS), Setuju (S), Tidak Setuju (TS) dan Sangat Tidak Setuju (STS) yang harus dilakukan oleh responden dengan cara memberikan tanda centang $(\sqrt{ })$ pada kolom yang tersedia (Sugiono,2016: 135). Kedua kelas kemudian dikelompokan berdasarkan kemandirian belajar tinggi, sedang dan rendah.

Tabel 2. Sistem Penilaian Angket

\begin{tabular}{|c|c|c|c|}
\hline $\begin{array}{c}\text { Pernyataan Positif } \\
\begin{array}{c}\text { Jawaban Butir } \\
\text { Instrumen }\end{array}\end{array}$ & Skor & Skor & $\begin{array}{c}\text { Jawaban Butir } \\
\text { Instrumen }\end{array}$ \\
\hline Sangat Setuju & 4 & 1 & Sangat Setuju \\
\hline Setuju & 3 & 2 & Setuju \\
\hline Tidak Setuju & 2 & 3 & Tidak Setuju \\
\hline Sangat Tidak Setuju & 1 & 4 & Sangat Tidak Setuju \\
\hline
\end{tabular}

Pada penelitian eksperimen ini, skala Likert digunakan utuk mengetahui tingkat kamandirian belajar siswa yang berperan sebagai variabel moderator. Kriteria pengelompokan berdasarkan kemandirian belajar dapat dilihat pada tabel III. dibawah ini:

Tabel 3. Kriteria Pengelompokan Kemandirian Belajar Siswa

\begin{tabular}{|c|c|}
\hline Syarat Penilaian & Kategori \\
\hline$x \leq \bar{x}-S D$ & Rendah \\
\hline $\bar{x}-S D<x<\bar{x}+S D$ & Sedang \\
\hline$x \geq \bar{x}+S D$ & Tinggi \\
\hline
\end{tabular}




\section{HASIL DAN PEMBAHASAN}

Berdasarkan hasil perhitungan yang telah dilakukan, diperoleh kriteria pengelompokkan kemandirian belajar siswa sebagai berikut:

Tabel 4. Kriteria Pengelompokkan Kemandirian Belajar Siswa

\begin{tabular}{|c|c|}
\hline Kriteria & Keterangan \\
\hline$x \leq 80,07$ & Rendah \\
\hline $80,07<x<97,09$ & Sedang \\
\hline$x \geq 97,09$ & Tinggi \\
\hline
\end{tabular}

Analisis pengelompokan kemandirian diatas, maka diperoleh untuk kelas eksperimen 6 orang berkemandirian belajar tinggi, 15 orang berkemandirian belajar sedang dan 4 orang berkemandirian belajar rendah. Sedangkan untuk kelas kontrol diperoleh 4 orang berkemandirian belajar tinggi, 15 orang berkemandirian belajar sedang dan 6 orang berkemandirian belajar rendah.

Setelah siswa dikelompokan berdasarkan kemandirian belajar, maka sebelum masuk ketahap perlakuan siswa terlebih dahulu diberikan soal pretest kemampuan berpikir kreatif untuk melihat bahwa kedua kelas dalam kondisi awal yang sama. Analisis data pretest ini menggunakan uji $\mathrm{t}$, yang mana sebelum dilakukan uji $\mathrm{t}$ terlebih dahulu dilakukan uji prasayarat yaitu data berdistribusi normal dan homogen. Perhatikan tabel dibawah ini:

Tabel 5. Uji Normalitas Soal Pretest

\begin{tabular}{|c|c|c|l|}
\hline Kelas & $\boldsymbol{L}_{\text {hitung }}$ & $\boldsymbol{L}_{\text {tabel }}$ & Kriteria \\
\hline Eksperimen & 0,1211 & 0,173 & Normal \\
\hline Kontrol & 0,1394 & 0,173 & Normal \\
\hline
\end{tabular}

Tabel 6. Uji Homogenitas Soal Pretest

\begin{tabular}{|c|c|c|c|c|}
\hline Nilai Varians & \multicolumn{2}{|c|}{ Kelas } & \multirow{2}{*}{ F $_{\text {hitung }}$} & \multirow{2}{*}{$\mathbf{F}_{\text {tabel }}$} \\
\cline { 2 - 3 } Sampel & Eksperimen & Kontrol & & \multirow{2}{*}{1,0342} \\
\hline$S^{2}$ & 116,2084 & 112,3600 & \multirow{2}{*}{1,98} \\
\hline $\mathrm{N}$ & 25 & 25 & & \\
\hline
\end{tabular}

Tabel 7. Uji t Pretest

\begin{tabular}{|c|c|c|}
\hline $\boldsymbol{t}_{\text {hitung }}$ & $\boldsymbol{t}_{\text {tabel }} \mathbf{5} \%$ & Keterangan \\
\hline 0,1296 & 2,0106 & $H_{a}$ ditolak \\
\hline
\end{tabular}

Dengan $d k=48$ dengan taraf signifikan $5 \%$ diperoleh $t_{\text {tabel }}$ sebesar 2,0106. Hal ini berarti bahwa $t_{\text {hitung }}<t_{\text {tabel }}$. Maka dapat ditarik kesimpulan bahwa $H_{0}$ diterima dan $H_{a}$ ditolak yang berarti "tidak terdapat perbedaan kemampuan berpikir kreatif matematika antara siswa kelas eksperimen dan kelas kontrol".

Hasil uji hipotesis kemampuan berpikir kreatif dapat dilihat pada tabel dibawah ini:

Tabel 8. Hasil Normalitas Soal Pascatest

\begin{tabular}{|l|l|l|l|}
\hline Kelas & $L_{\text {hitung }}$ & $L_{\text {tabel }}$ & Hasil \\
\hline
\end{tabular}




\begin{tabular}{|c|l|l|l|}
\hline Eksperimen & 0,1279 & 0,173 & Normal \\
\hline Kontrol & 0,0983 & 0,173 & Normal \\
\hline
\end{tabular}

Tabel 9. Uji Homogenitas Soal Pascatest

\begin{tabular}{|c|c|c|c|c|}
\hline \multirow{2}{*}{$\begin{array}{c}\text { Nilai Varians } \\
\text { Sampel }\end{array}$} & \multicolumn{2}{|c|}{ Kelas } & \multirow{2}{*}{$\mathbf{F}_{\text {hitung }}$} & \multirow{2}{*}{$\mathbf{F}_{\text {tabel }}$} \\
\cline { 2 - 3 } & Eksperimen & Kontrol & & \multirow{2}{*}{1,5406} \\
\hline$S^{2}$ & 83,1744 & 128,1424 & 1,98 \\
\hline $\mathrm{N}$ & 25 & 25 & & \\
\hline
\end{tabular}

Tabel 10. Hasil Tes " $t$ "

\begin{tabular}{|c|c|c|}
\hline Nilai $\boldsymbol{t}$ hitung & Nilai $\boldsymbol{t}$ table & Hasil \\
\hline 2.8235 & 2,0106 & $H_{a}$ diterima \\
\hline
\end{tabular}

Pada hipotesis pertama berdasarkan hasil analisis data tentang kemampuan berpikir kreatif matematis siswa pada pokok bahasan trigonometri tersebut menunjukkan bahwa rata-rata kemampuan berpikir kreatif matematis siswa yang menggunakan model pembelajaran Problem Based Instruction (PBI) lebih tinggi dari rata-rata siswa yang menggunakan model pembelajaran konvensional. Hasil analisis data dengan menggunakan uji tes $\mathrm{t}$ menunjukkan nilai $t_{\text {hitung }}=$ $2,7500>t_{\text {tabel }}=2,0106$. maka $H_{a}$ diterima dan $H_{o}$ ditolak., maka dapat disimpulkan Terdapat perbedaan kemampuan berpikir kreatif matematis antara siswa yang mengikuti model pembelajaran Problem Based Instruction (PBI) dengan siswa yang belajar mengikuti pembelajaran konvensional di SMA Negeri Plus Provinsi Riau.

Tabel 11. Hasil Uji Anova Dua Arah

\begin{tabular}{|c|c|c|c|c|c|c|}
\hline $\begin{array}{l}\text { Sumber } \\
\text { Variansi }\end{array}$ & Dk & JK & RK & Fh & Fk & Kesimpulan \\
\hline $\begin{array}{c}\text { Antar Baris } \\
\text { (Model) A }\end{array}$ & 1 & 832,32 & 832,32 & 20,76 & 4,06 & $\begin{array}{lr}\text { Terdapat } & \text { pengaruh faktor } \\
\text { model } & \text { pembelajaran } \\
\text { terhadap } & \text { Kemampuan } \\
\text { Berpikir Matematis Siswa }\end{array}$ \\
\hline $\begin{array}{c}\text { Antar Kolom } \\
\text { (Kemandiriaan } \\
\text { Belajar) B }\end{array}$ & 2 & 3650,65 & 1825,33 & 45,53 & 3,21 & $\begin{array}{l}\text { Terdapat pengaruh faktor } \\
\text { Kemandirian } \\
\text { terhadap Belajar } \\
\text { Berpikir Kreatif Matematis } \\
\text { Siswa }\end{array}$ \\
\hline $\begin{array}{c}\text { Interaksi } \\
\text { kemandirian } \\
\text { belajar*model } \\
\left(\mathbf{A}^{*} \mathbf{B}\right)\end{array}$ & 2 & $-345,35$ & $-172,68$ & $-3,52$ & 3,21 & $\begin{array}{lr}\text { Tidak terdapat } & \text { pengaruh } \\
\text { interaksi antara } & \text { model } \\
\text { pembelajaran } & \text { dengan } \\
\text { Kemandirian } & \text { Belajar } \\
\text { terhadap } & \text { Kemampuan } \\
\text { Berpikir Kreatif } & \text { Matematis } \\
\text { Siswa } & \end{array}$ \\
\hline Dalam & 44 & 1763,90 & 49,09 & & & \\
\hline Total & 49 & 5901,52 & - & & & \\
\hline
\end{tabular}

Pada tabel diatas dapat dilihat bahwa Pada hipotesis kedua, jika dilihat berdasarkan kemandirian belajar siswa maka mean siswa berkemandirian belajar kelompok tinggi, sedang dan rendah kelas eksperimen lebih tinggi dibandingkan mean kelas kontrol. Hasil analisis data untuk hipotesis kedua dengan menggunakan anova dua arah (two way anova) untuk melihat perbedaan 
kemampuan berpikir kreatif matematis siswa ditinjau dari kemandirian belajar menunjukkan nilai $F(B)_{\text {hitung }}=45,53$ dan $F(B)_{\text {tabel }}=3,21$ pada taraf signifikan $5 \%$. Dengan kesimpulan $F(B)_{\text {hitung }}>F(B)_{\text {tabel }}$ yang berarti $H_{a}$ diterima dan $H_{0}$ ditolak. Hal ini berarti terdapat perbedaan kemampuan berpikir kreatif matematis antara siswa yang memiliki kemandirian belajar tinggi, sedang dan rendah. Dengan demikian dapat diambil kesimpulan bahwa berdasarkan aspek kemandirian belajar, terdapat perbedaan kemampuan berpikir kreatif matematis antara siswa yang mengikuti pembelajaran Problem Based Instruction (PBI) dengan siswa yang mengikuti pembelajaran konvensional di SMA Negeri Plus Provinsi Riau.

Analisis data untuk hipotesis ketiga dengan menggunaka anova dua arah (two way anova) menunjukan nilai $F(A \times B)_{\text {hitung }}=-3,52$ dan $F(A \times B)_{\text {tabel }}=3,21$ pada taraf signifikan $5 \%$. Dengan kesimpulan $F(A \times B)_{\text {hitung }}<F(A \times B)_{\text {tabel }}$ yang berarti $H_{0}$ diterima dan $H_{a}$ ditolak, sehingga dapat ditunjukan bahwa tidak terdapat interaksi faktor kemandirian belajar terhadap kemampuan berpikir kreatif matematis siswa. Dengan demikian dapat disimpulkan bahwa model pembelajaran bersama-sama dengan kemandirian belajar tidak mempengaruhi kemampuan berpikir kreatif matematis siswa atau dengan kata lain tidak terdapat interaksi antara pembelajaran Problem Based Instruction (PBI) dan kemandirian belajar dalam mempengaruhi kemampuan berpikir kreatif matematis siswa di SMA Negeri Plus Provinsi Riau.

\section{KESIMPULAN}

Terdapat perbedaan kemampuan berpikir kreatif matematis antara siswa yang mengikuti model pembelajaran Problem Based Instruction (PBI) dengan siswa yang mengikuti pembelajaran konvensional di SMA Negeri Plus Provinsi Riau. analisis data dengan menggunakan uji tes $\mathrm{t}$ menunjukkan nilai $t_{\text {hitung }}=2,7500>t_{\text {tabel }}=2,0106$ signifikan $5 \%$. Dengan kesimpulan $t_{\text {hitung }}>t_{\text {tabel }}$ yang berarti $H_{a}$ diterima dan $H_{0}$ ditolak. Terdapat perbedaan kemampuan berpikir kreatif matematis antara siswa yang memiliki kemandirian belajar tinggi, sedang dan rendah, hal ini dilihat dari hasil analisis data dengan menggunakan anova dua jalan menunjukan $F(B)_{\text {hitung }}=32,80$ dan $F(B)_{\text {tabel }}=3,21$ pada taraf signifikan $5 \%$. Dengan kesimpulan $F(B)_{\text {hitung }}>F(B)_{\text {tabel }}$ yang berarti $H_{a}$ diterima dan $H_{0}$ ditolak. Hal ini berarti berdasarkan kemandirian belajar, terdapat perbedaan kemampuan berpikir kreatif matematis antara siswa yang mengikuti model pembelajaran Problem Based Instruction (PBI) dengan siswa yang mengikuti pembelajaran konvensional di SMA Negeri Plus Provinsi Riau. Tidak terdapat interaksi faktor kemandirian belajar terhadap kemampuan berpikir kreatif matematis siswa Hasil analisis data dengan menggunakan anova dua arah (two way anova) menunjukan nilai $F(A \times B)_{\text {hitung }}=-2,20$ dan $F(A \times B)_{\text {tabel }}=3,21$ pada taraf signifikan $5 \%$. Dengan kesimpulan $F(A \times B)_{\text {hitung }}<$ $F(A \times B)_{\text {tabel }}$ yang berarti $H_{0}$ diterima dan $H_{a}$ ditolak. Berdasarkan hasil tersebut dapat menjawab dari judul yang diangkat oleh peneliti yaitu Pengaruh Penerapan Model Pembelajaran Problem Based Instruction terhadap Kemampuan Berpikir Kreatif Matematis berdasarkan Kemandirian Belajar Sekolah Menengah Atas Negeri Plus Provinsi Riau.

\section{REFERENSI}

Amir Z dan Risnawati.(2015).Psikologi Pembelajaran Matematika.Yogyakarta: Aswaja Pressindo.

Anggraini.(2012)."Pengaruh Model Pembelajaran Scientific Inquiry dan kemampuan berpikir kreatif terhadap keterampilan Proses Sains di SMA N 1 Stabat". Jurnal Pasca Sarjana Universitas Negeri Medan.

Asti Asterina.(2015)."Peningkatan Kemampuan Berpikir Kritis Dankreatif Matematis Melalui Pembelajaran Problem Centered Learning Siswa SMP”(Bandung:Universitas Pendidikan Indonesia,2015.

B Uno, H \& Mohamad,N.(2012).Belajar dengan Pendekatan P AIKEM.Jakarta:Bumi Aksara. 
Hedi Budiman.(2011)"Peningkatan Kemampuan Berpikir Kritis Dan Kreatif Matematis Siswa Melalui Pendekatan Pembelajaran Berbasis Masalah Berbantuan Software Cabri 3D”, 2. Artikel Ilmiah.

Hendriana „H \& Sumarmo,U.(2017).Hard Skills dan Soft Skills Matematik Siswa, (Bandung:PT Repika Aditama.

Lestari,K E \& Ridwan,M.(2017).Penelitian Pendidikan Matematika.Bandung:PT Refika Aditama.

Masrun dkk.(1986)."Studi Mengenai Kemandirian pada Penduduk di Tiga Suku Bangsa(Jawa,Batak,Bugis)”, Laporan Penelitian, Universitas Gajah Mada.

OECD.(2015). Programe For International Student Assessment (PISA) Results From PISA 2015. [online]. Tersedia: http://www.oecd.org/unitedstates/PISA-2015-results-US.pdf

Okviani Syafti.(2016) 'Pengaruh Problem Based Instruction Terhadap Kemampuan Berpikir Kreatif Matematis Siswa Kelas X SMA Negeri Kabupaten Pesisir Selatan”.Jurnal Kepemimpinan dan Pengurusan Sekolah.Volume I Nomor 2.

Ramon Muhandaz.(2015)."Pengaruh Model Pembelajaran Kooperatif Tipe Investigasi Kelompokt terhadap Pemecahan Masalah Matematis Siswa Kelas VIII MTsN Kota Padang," Suska Jurnal of Mathematics Education Vol. 1 No.

Sanjaya,Wina.(2013).Penelitian Pendidikan: Jenis, Metode, Prosedur.Jakarta: Kencana.

Slameto.(2015).Belajar dan Faktor-Faktor yang Mempengarubi.Jakarta:PT Rineka Cipta.

Syam, Suardi.(2015).Psikologi Perkembangan Peserta Didik. Yogyakarta:Zanafa Publishing.

Trianto.(2017).Mendesain Model Pembelajaran Inovatif, Progresif dan Kontekstual.Jakarta: Kencana.

Widiani Tresia.(2016)."Penerapan Pendekatan Saintifik Dan Pengarubnya Terbadap Kemampuan Komunikasi Matematis Dan Berpikir Kreatif Siswa", Pontianak: Universitas Tanjungpura. 